\title{
Intertwining Christian Mission, Theology, and History: A Case Study of the Basel Mission among the Thiyyas and Badagas of Kerala, 1870-1913
}

Tiasa Basu Roy

\section{check for}

updates

Citation: Basu Roy, Tiasa. 2021. Intertwining Christian Mission,

Theology, and History: A Case Study of the Basel Mission among the Thiyyas and Badagas of Kerala, 1870-1913. Religions 12: 121. https://doi.org/10.3390/rel12020121

Academic Editor: Carlos

F. Cardoza-Orlandi

Received: 30 December 2020

Accepted: 9 February 2021

Published: 15 February 2021

Publisher's Note: MDPI stays neutral with regard to jurisdictional claims in published maps and institutional affiliations.

Copyright: (c) 2021 by the author Licensee MDPI, Basel, Switzerland. This article is an open access article distributed under the terms and conditions of the Creative Commons Attribution (CC BY) license (https:// creativecommons.org/licenses/by/ $4.0 /)$
Department of History, Visva-Bharati University, Bolpur 731235, India; tiasabasuroy3@gmail.com

\begin{abstract}
For centuries, various denominations of Christian missionaries have contributed in a larger way towards the spread of Christianity among the people of Indian sub-continent. Each Church had its own principles of preaching the word of God and undertook welfare activities in and around the mission-stations. From establishing schools to providing medical aids, the Christian missionaries were involved in constant perseverance to improve the 'indigenous' societies not only in terms of amenities and opportunities, but also in spiritual aspects. Despite conversion being the prime motive, every Mission prepared ground on which their undertakings found meanings and made an impact over people's lives. These endeavours, combining missiological and theological discourses, brought hope and success to the missionaries, and in our case study, the Basel Mission added to the history of the Christian Mission while operating in the coastal and hilly districts of Kerala during the 19th and the 20th centuries. Predominantly following the trait of Pietism, the Basel Mission emphasised practical matters more than doctrine, which was evident in the Mission activities among the Thiyyas and the Badagas of Malabar and Nilgiris, respectively. Along with addressing issues like the caste system and spreading education in the 'backward' regions, the most remarkable contribution of the Basel Mission established the 'prototype' of industries which was part of the 'praxis practice' model. It aimed at self-sufficiency and provided a livelihood for a number of people who otherwise had no honourable means of subsistence. Moreover, conversion in Kerala was a combination of 'self-transformation' and active participation which resulted in 'enculturation' and inception of 'modernity' in the region. Finally, this article shows that works of the Basel Mission weaved together its theological and missiological ideologies which determined its exclusivity as a Church denomination.
\end{abstract}

Keywords: Basel Mission; Christianity; conversion; industries; South India; untouchable; tribe

\section{Brief History of Christianity in Kerala}

Christianity in India, over the many centuries of its presence, has a deep connection with the Indian culture and is no means a mere survivor of European colonialism and foreign missions (Shah and Carpenter 2018). To quote Robert Frykenberg (2008, p. viii), 'nowhere in the world today are existing non-Western forms of Christianity older or more complex than in India'. Perhaps the first to respond to Christian missions was Kerala (Raghaviah 2017), ${ }^{1}$ which carries a long tradition of Christianity (including both the 'Greater and Lesser traditions'), as shown by the presence of several generations of dedicated men and women who undertook the responsibility of spreading the word of God among the people. This resulted in the establishment of a number of Churches and the organization of mission movements in this region (Philip 2000, p. 300). The evangelical activities of Christian missions began with the age of discovery, and India's connection

1 At the beginning of the 19th century, Kerala remained as three distinct political and administrative entities. These were the Princely States of Travancore and Cochin, which operated with relative independence under the suzerainty of the English East India Company, and the newly created District of Malabar (Raghaviah 2017). 
with Christianity is claimed to be from A.D. 52, when St. Thomas, one of the 12 disciples of Jesus Christ, landed on the West coast of South India. The Portuguese came to the Malabar Coast on 24 December 1500, following the footsteps of Vasco Da Gama, who was the first to reach Calicut in A.D. 1498. As a result, the Jesuit missions began to operate in India on the coastal region, particularly among the fishing Parava population. In the 17th century, Robert de Nobili, after being inspired by St. Thomas, followed a policy of accommodation which allowed a large number of people from various backgrounds (in terms of religion and sect) to be a part of the Christian community (Thonippara 2000, p. 60; Hedlund 2016). The active missionary movements of the 19th and 20th centuries were largely a Protestant evangelical phenomenon. The missionary movement from the West was an historical reality in countries like India (Nesamony 2016), and Protestant missions like the London Missionary Society (L.M.S.), the Church Missionary Society (C.M.S.), and the Basel Mission Society (B.M.S.) triggered several social reform movements, especially amongst Dalits, Adivasis, and Bahujan communities in Kerala. While L.M.S. focused its works in Southern Travancore (parts of which fall in the present-day Tamil Nadu), and C.M.S. worked in Central Travancore, and the Basel Mission organized its activities in the Malabar and the Nilgiris (Copley 2000, pp. 33-37). However, the Asian roots of the Church lay deeper than the traditions, and the Malabar Christians formed themselves into a distinct religious group (Padhmanabhamenon 1983, pp. 444-45)2.

Scholars have largely worked on conversion movements in South India (see map, Figure 1) among the outcastes like the Pulayas, Parayas, Nadars, Madharis, and Goundars from an empirical and anthropological perspectives (Cederlöf 1997; Viswanath 2014; Basu 2011; Mohan 2015; Bugge 1994; Kumaradoss 2007; Kent 2004; Harding 2008; Kooiman 1989; Bayly 1989; Gladstone 1984; Hardgrave 1969). Questions regarding motives behind conversion and social issues relating to it have been discussed analytically as separate case studies. 'Mass conversion' in the late 19th and early 20th centuries to either Islam or Christianity has been interpreted mostly in the light of politicisation and mobilisation of the 'untouchable' castes whose conscious effort was to either raise their social and economic status or escape from the clutches of the Hindu landlords (Cederlöf 1997). Scholars like Duncan Forrester (1977), however, had been passionate about the low castes and suggested that conversion was out of 'a genuine search for spiritual movement'. However, most interpretations point towards economic and materialistic gains that encouraged people to change their religious affiliation (Copley 2000; Mosse 2012). Along with themes like these, historians have also studied the contributions of Church Missions like the Wesleyan Methodist Missionary Society, the United Evangelical Lutheran Church of Germany, the Society for Promoting Christian Knowledge (SPCK), the Baptists, and the Presbyterians in great detail, which prepared grounds for the Christian conversion movement in the regions. All mission denominations had a more or less similar ideology of functioning, i.e., touring, preaching, and evangelization. Along with this, welfare activities in terms of providing education and medical facilities were corollary to the basic aim of the Christian missionaries in securing a good number of converts. However, developing a sense of self-reliance and self-resourcefulness among the converts by promoting vocational training and establishing a prototype of 'industries' are the exceptional features that made the Basel Mission Society stand out from the rest of its contemporaries.

2 [T]he tradition so clearly cherished by the Malabar Christians says that the Apostle Thomas landed at Malankara near Cranganore, founded seven churches or Christian communities in different stations in Malabar, and converted among others several families of Nambudiri Brahmans, notably the Kalli, Kaliankara, Shankarapuri, and Pakalomattam families, on the last two of which the Apostle conferred the peculiar privilege of supplying members for the priesthood [sic]. (Padhmanabhamenon 1983, pp. 444-45). 


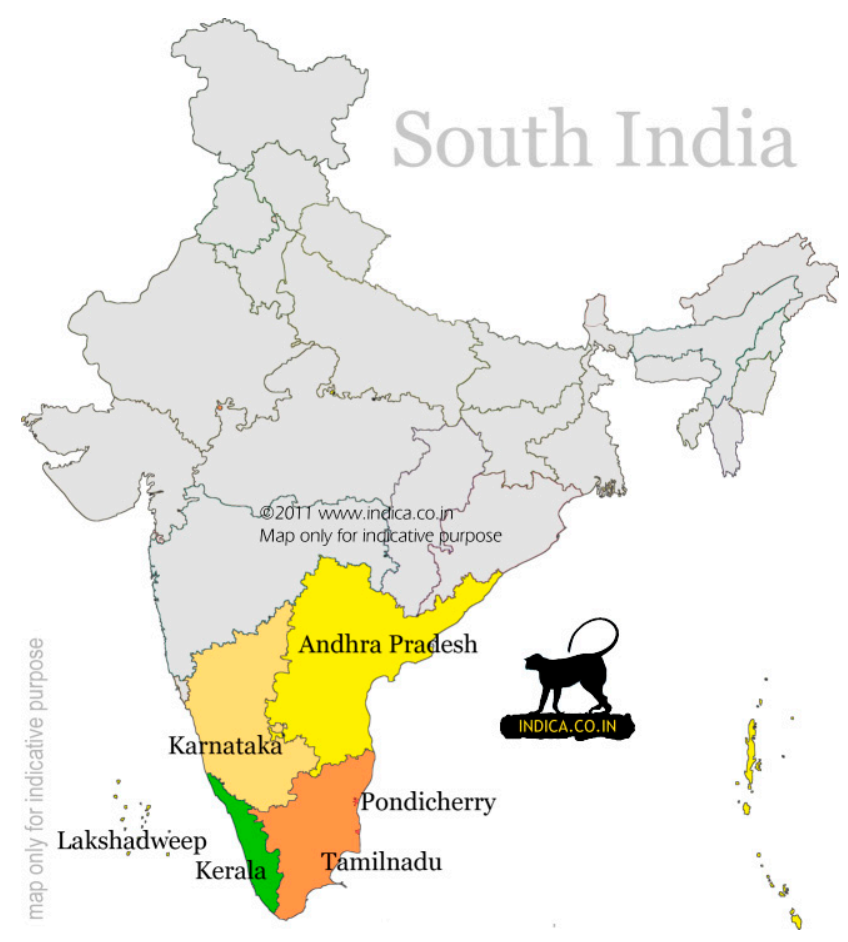

Figure 1. Map of India. The south Indian states are Andhra Pradesh, Tamil Nadu, Karnataka and Kerala. (https://visimaps.blogspot.com/2016/04/south-india-map.html, accessed on 13 February 2021).

Previous writings oriented the mission activities mainly in understanding the class relation and its mechanism in the society and in showing how missionaries came as apologists to the outcastes and tribes to protest against upper-caste Hindu oppression (Kooiman 1989). ${ }^{3}$ However, not all identified missionary assistance as acts of benevolence. Historians like K.M. Panikkar (1953) and Hobson (1902) projected the Christian missionaries as agents of 'an aggressive cultural imperialism' and that their contributions were meant to affect the mental health and spirituality of the 'colonised' ${ }^{4}$ According to them, Protestant missionary evangelism and European imperial expansion were complementary aspects which ultimately led to a communal divide between the Christian converts and the nonconverts, similar to that of the Hindus and Muslims (Bayly 1989). In contrast to these arguments, Brian Stanley (1990) and Andrew Porter (2004) vouched that the relation between the Church and the State was characteristically 'temporary, grudging, and selfinterested'. For them, evangelism and imperial expansion were not two sides of the same coin.

This paper seeks to examine how the Basel Mission worked in conformity with its primary belief of active piety (praxis pietatis) over doctrine with principles of selfresourcefulness (known for its 'industries', workshops, printing, and publishing) and individual preaching and evangelisation among the Thiyyas and the Badagas of Malabar and Nilgiris respectively. Moreover, the Christian conversion in Kerala will be theoretically

3 A similar experience is gathered from Tswana, where the Christian missionaries got involved in local struggles; contests over gender roles, agriculture, and social order; and made appropriations to make Christianity an 'indigenous' religion which appeared appealing to the local population (Comaroff and Comaroff 2001).

4 To quote the words of T.O. Beidelman (1982, p. 5), 'Christian missionaries represent the most naïve and ethnocentric, and therefore, the most thorough-going, facet of colonial life ... Missionaries invariably aimed at overall changes in the beliefs and actions of native people, at colonization of heart and mind as well as body. Pursuing this sustained policy of change, missionaries demonstrated a mode radical and morally intense commitment to rule than political administrators or businessmen'. 
analysed on the basis of social-psychological and social-historical models ${ }^{5}$ by portraying the agrarian scenario of the regions and the ethnographic overview of the ethnic communities, understanding their positions and roles as individuals in the society, and then contextualise the situation in which the Basel missionaries operated to find out whether the converts witnessed 'self-transformation' or were 'passive recipients' of Christianity. It will also uncover whether the conversion experiences in the regions fit to the Seven Stage Model of Lewis R Rambo. ${ }^{6}$ In order to identify these traits, I have relied primarily on the Basel Mission Reports. However, being aware of the nuances of prejudice and interpretative conflicts of the incidents from these mission narratives, I have referred to a number of anthropological and historical works in South India to balance the analytical overview and present an impartial account of my case studies. Finally, this research will draw a tangent on how mission, theology, and history interacted in the conversion experiences among the 'untouchable' and the 'tribal' communities in the regions.

\section{The Agrarian World of Malabar and the Nilgiris}

Geographically, South India is divided into two areas-the coastal belt and the interior plateau region. Except for the two coastal areas and the delta of rivers, most parts of South India have poor soil and scanty rainfall, creating inhospitable conditions for agriculture (Alexander 1980).

Malabar (Logan 1906) ${ }^{7}$ (see map, Figure 2), which extends from north to south along the southern part of the western coast, formed a part of the Ryotwari settlement. In principle, the Ryotwari system was a contract between the cultivator, the ryot, and the state in paying land tax. This system, although it strengthened peasants' rights, had serious distortions when implemented by the British. Interestingly, agrarian land relations and occupations were closely linked with the existing hierarchical caste structure, determining the access to a particular profession, which was 'typically' an Indian framework of working and 'mode of production' (Raghaviah 2017; Cederlöf 1997). Along with this, caste divisions were carried to root levels manifesting as 'unapproachability' and 'polluting distances', which adversely affected social communications. For example, a Pulaya, an outcaste, had to keep a distance of 16 feet from a Thiyya, who also belonged to the outcaste group but had a comparatively better social position. Similarly, the latter had to keep the same distance

5 Social-psychological and social-historical were two models used by S. Masondo to theorise conversion in the African context. In the first category, conversion was studied as self-transformative, where an individual played the central role after taking into account the transformation of the 'real self' and that the Africans were not 'passive recipients of either Islam or Christianity', and the second one viewed conversion within a broader framework of socio-political, economic, and historical context. The 'social-historical' model is similar to that of Snow and Machalek's 'socio-rhetorical' model, which identifies the convert as a product of a social context. These two approaches combinedly explained the 'multi-causal' conversion motives in Africa. (Masondo 2015; Horton 1971; Hefner 1993; Metuh 1987; Staples and Mauss 1987; Snow and Machalek 1983).

6 Rambo designed a seven-stage sequential model which was appropriate in showing that religious conversion was a process of change over time. The various stages were context, crisis, quest, encounter, interaction, commitment, and consequences. To quote his words, 'Conversion is paradoxical. It is elusive. It is inclusive. It destroys and it saves. Conversion is sudden and it is gradual. It is created totally by the action of God, and it is created totally by the actions of humans. Conversion is personal and communal, private and public. It is both passive and active. It is a retreat from the world. It is a resolution of conflict and an empowerment to go into the world and confront, if not create, conflict. Conversion is an event and a process. It is an ending and a beginning. It is final and open-ended. Conversion leaves us devastated-and transformed' (Rambo 1993, pp. 3, 176).

7 The Malabar coastline is about 150 miles, lying between North Latitude $10^{\circ} 115^{\prime}$ and $12^{\circ} 118^{\prime}$ and East Longitude $75^{\circ} 14^{\prime}$ and $76^{\circ} 56^{\prime}$. The coast line of Malabar proper stretches from north (northwest) to south (southeast), and the distance of inland from the coast varies from $32 \mathrm{~km}$ to $241 \mathrm{~km}$. The district can be seen vertically divided into three sections, i.e., the malanad (hill area) comprising of the Western Ghats, the edanad (midlands) forming the hilly terrain, and the long coast line referred to as theera pradesham (coast). The district covers around 14,460 sq. $\mathrm{km}$ (Logan 1906). 
from a Nair, and this went on in a 'bottom-up' order. (Raghaviah 2017; Menon 1933; Pillai 1970). ${ }^{8}$

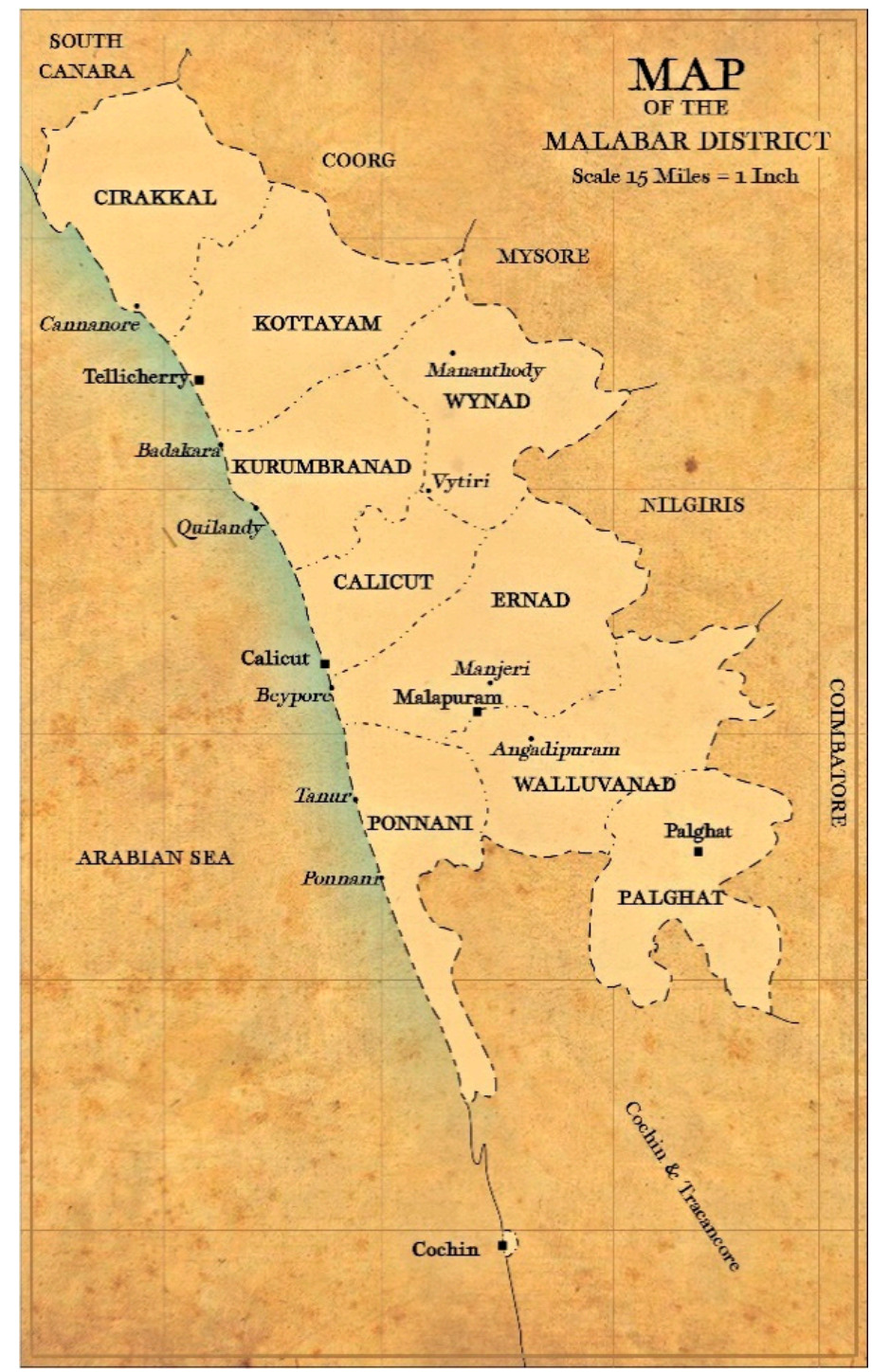

Figure 2. Source: Created by referring to the Gazetteer and other records. Geographical extent of the Malabar District, Kerala with its revenue divisional head-quarters and Taluks. Cirakkal, Kottayam, Wayanad, Kurumbranad, Calicut, Ernad, Ponnani, Walluvanad, and Palghat together form the Malabar. (https:/ / upload.wikimedia.org/wikipedia/commons/f/fb/Malabar_District_Map.jpg, accessed on 20 January 2021).

8 An instance can be put here to show how rigorous was the concept of 'untouchable' with the Pulayas. An infant of two years old, labouring under a defect of sight which seemed to require a surgical operation, Mr. Brown sent him with his father, one of his Pooliyar, to Tellicherry where Dr Richmond had kindly offered to perform the operation if necessary. He and the child went down by water, though it was with some difficulty that Mr. Brown got the teerboat-men, his own people to admit them into his own boat. On returning from Tellicherry they did not have this benefit of conveyance and had to come by land; compelled whenever they came in sight of a habitation, to fly from the public high road and make a long circuit to avoid the remotest approach; forced to utter a cry at every step they took, to give warning to others that a human being and not a dog was coming and driven, whenever their cry answered, to hide themselves in the jungle until their superior, probably a fisherman or salt maker, had passed. Thus, it is that the right of public way, which is freely conceded to every beast of the field, is denied to a whole class of human beings. Even the mere interruption of this right is justly considered as a high misdemeanour, what then ought its prohibition to be? This horrible tyranny is a remnant of that which the higher castes formerly exercised upon the lower; but as the British Government has never tolerated it in the instance of the other castes, so Mr. Brown earnestly requested its authority to withdraw the unhappy Pooliyar from a condition which ranked them beneath the lowest brute. Extract from F.C. Brown, Esq. to the Principal Collector and Magistrate of Malabar, 16th August 1832, pp. 412-13 in Slave trade (East India)—Slavery in Ceylon (Vol. 16)—ordered by The House of Commons, 31 July 1838; Disposal Jacket No. 286/1813-1880. 
The Nilgiris or the Blue Hills is the north eastern Hill district of Tamil Nadu and is bounded by the States of Karnataka in the North; Kerala in the West and two districts of Tamil Nadu—Coimbatore in the South and Erode in the East (see map, Figure 3) ${ }^{9}$. This district is basically a horticulture district, and its entire economy depends upon the success and failure of horticulture crops like potato, cabbage, carrot, spices, and fruits. However, the main cultivation is plantation crops like tea and coffee (Chand et al. 2009). Both adivasis (tribals) and non-adivasis depended on agriculture as their source of livelihood along with primary occupations like collecting forest produce, pastoralists, and artisans (Menon et al. 2008, p. 22). Shifting cultivation was primarily practiced by the inhabitants, but changes in agrarian patterns started with the advent of the Europeans, who introduced terracing the slopes and preparing the lands, cattle-drawn ploughs, irrigation systems, commercial and economic plants, etc. Plantation labour, especially in the estate sector, consisted of various adivasis like the Kanikkar and Muthuvar of Thiruvithamkur, Badagas and Thodar of Nilgiri and the Naicker, Paniyar and Kurumbar of Wayanad. The Nilgiri district comprises the Upper and the Lower Nilgiris. In the Upper Nilgiris, tea was cultivated mostly by the Badaga community over almost four decades, while in the Lower Nilgiris, in the Gudalur region, the populace is mainly comprised of the tribal people along with the Sri Lankan Repatriates (Sarkar and Rasaily 2019, pp. 1-3, 28-29; Cederlöf 2002).

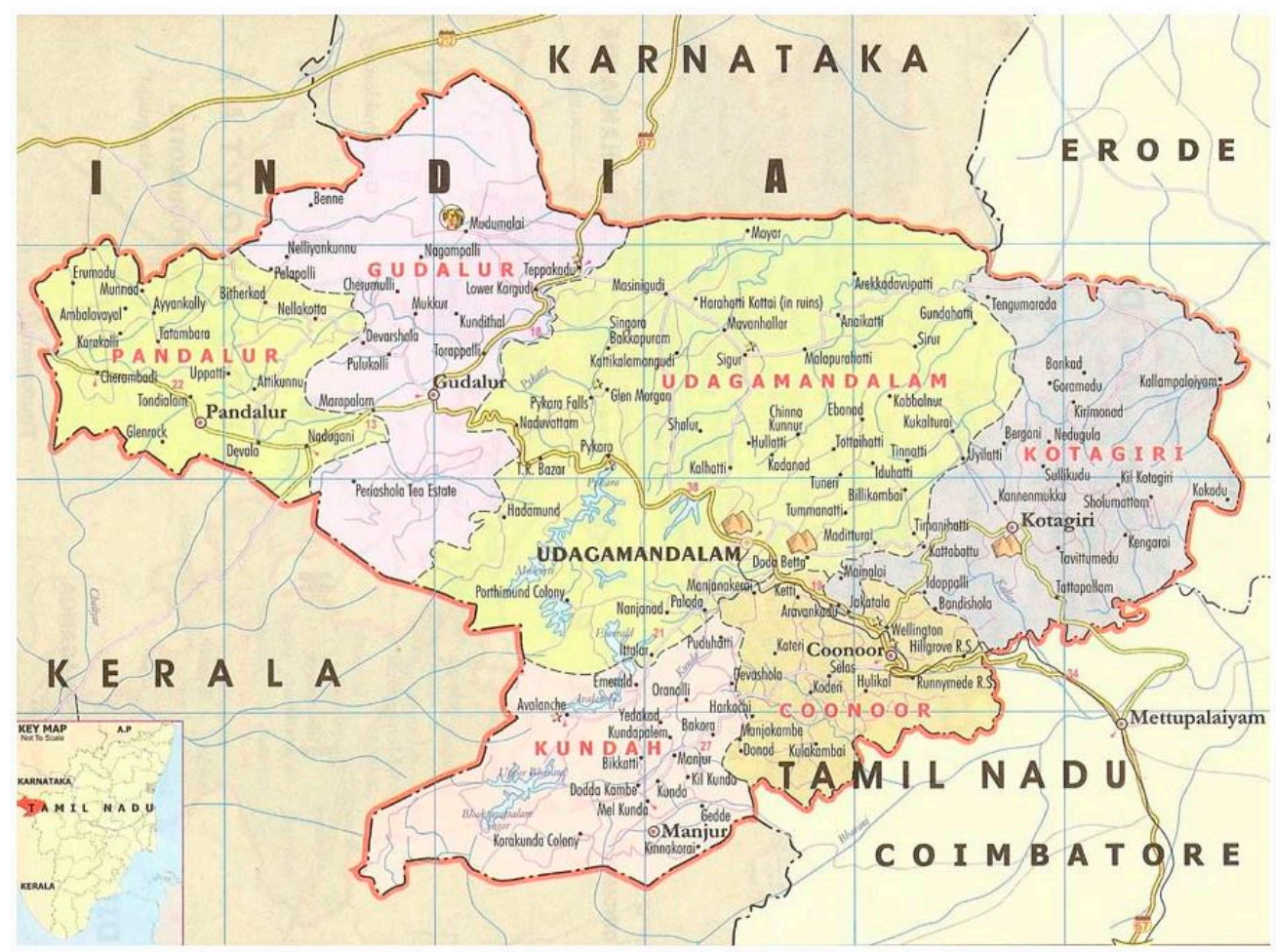

Figure 3. Source: Geographical position of the Nilgiris bounded by the states of Karnataka, Tamil Nadu, and Kerala (https:/ / badaga.files.wordpress.com/2018/04/nilgiris.jpg, accessed on 13 February 2021).

9 The plateau has been divided, as per the Badaga tradition, into four Nadus (divisions) called Peranganadu, Mekunadu, Todhanadu, and Kundhanadu. Nilgiris is the oldest mountain range, located at the tri-junction of Tamil Nadu, Kerala and Karnataka. Nilgiris is a part of the Western Ghats. Ooty, the 'Queen of Hill Stations'; Coonoor, 19 kilometers from Ooty; and Kotagiri, 31 kilometers from Ooty, are the three hill stations of this district. Nilgiris is India's first biosphere. It has been declared as one of the 14 'hot spots' of the world because of its unique biodiversity. The name 'Nilgiris' means Blue Hills (neelam-blue, and giri-hill or mountain). The first mention of this name is found in the Silappadikaram. There is a belief that the people living in the plains at the foot of the hills, should have given the name, the Nilgiris, in view of the violet blossoms of the kurinji flower periodically enveloping the hill ranges. The earliest reference to the political history of the Nilgiris, according to W. Francis, relates to the Ganga Dynasty of Mysore. Ooty, otherwise called Udhagamandalam, is the capital of the Nilgiri district. The economic activities of this district are accelerated through tourism to a considerable extent, which increases the income capacity of the people engaged in many fields. (Gopalakrishnan 1995, p. 4; 2001). 


\section{Ethnographic and Demographic Profile of Thiyyas and Badagas}

The Thiyyas formed the largest caste group in Malabar and were subjected to the rules of 'pollution' during the 19th and 20th centuries. They worked in palm groves, quarrying sectors, and as agricultural labourers and military servicemen (Logan 1906, p. 191). During British rule, ritual caste hierarchy put the highest ranking Nambuthiri Brahmins at the top, followed by the Nair caste. The middle tier consisted of the Muslims and the Thiyyas who were considered to be of 'polluting caste'; while the bottom was comprised of 'other polluting' castes such as the Cherumas, the Pulayas, and the local tribes (Miller 1954). ${ }^{10}$ This social structure corresponded to hierarchical access to economic resources and power, although regional variations existed within the Malabar region (Sam 2014, p. 33). The Thiyyas occupied the highest rank among the 'polluting castes' and exerted administrative control over others, either as landlords or as intermediaries in areas where a Nair tharavadu was dominant (Menon 1994, pp. 41-61; Miller 1954). Nevertheless, the Thiyyas experienced considerable disadvantages through restrictions of untouchability and unapproachability (Abraham 2010). One of them was differential access to the temple (kshetrams) and the shrines (kavus). While the Nairs and the Nambuthiris could worship at the kshetrams, the Thiyyas were allowed at the kavus only. So, during the temple festivals, the Thiyyas were expected to perform other ancillary services. However, in the kavu system of worship, the Thiyyas occupied a much higher status (Menon 1994, pp. 41-61). ${ }^{11}$ The Thiyyas continued to follow a variety of agrarian occupations during the colonial period, although they were most famously associated with the profession of toddy tapping, which was assumed to be their hereditary occupation in colonial ethnographies (Kodoth 2001). With the British colonisation of Malabar, a number of Thiyyas were middle-level agricultural tenants (Dhanagare 1977), and with the British introducing customary land rights to fit a legal framework of private ownership in India, many of these Thiyya tenants, as a consequence, were reduced to a level of poor peasants and agricultural wage labourers (Karat 1973).

On the other hand, the Blue Hills were the homeland of five distinct indigenous tribes such as the Badagas, the Todas, the Kotas, the Kurumbas and the Irulas (Cornish 1874, p. 327). ${ }^{12}$ The Badagas were and continue to be the most numerous in the region. The majority of them were cultivators of the soil, while some were collectors of honey and wax. It is held by some that, several centuries ago, they came from the northern part of Mysore as refugees

10 Malabar's Hindus are divided into upwards of 200 castes and sub-castes, between 15 and 25 of which are represented in nearly every village. They are culturally demarcated one from another, and they stand in a strict order of rank. As elsewhere in India, a caste often has a recognizable cultural uniformity throughout the linguistic area, and it may or may not be composed of more localized subcastes, with their own variations on culture of the caste as a whole. Other localized groupings are castes in their own right, in the sense that they are not part of any area-wide grouping. About $1 \%$ of Hindus are Nambudiri Brahmans, the highest caste. Until recently, their influence was disproportionate to their number. Besides being the Hindu religious heads, many were wealthy landlords with numerous lower-caste retainers. Nambudiris are patrilineal; the small ruling castes (Samantans, Kshattriyas) are matrilineal. So also are the Nayars, who form the Hindu 'middle class' and comprise about $20 \%$ of the Hindu population. Traditionally, the Nambudiris promulgated and interpreted the moral and ritual laws of the society at large, while the Nayars were responsible for maintaining the social order and the moral code in each local community. Nearly all Nayars were concerned in agriculture, and the upper sub-castes were soldiers in the service of the Rajas. All these, from Nayars upwards, are 'caste-Hindus'. Almost two-thirds of the Hindus are members of the polluting castes. High among these and larger than any other Hindu caste (about $35 \%$ of the total) are the matrilineal Thiyyas of North Malabar and the patrilineal Thiyyas and Iravans of South Malabar and Cochin. Some of them are small tenant cultivators; many are laborers. The artisan castes (blacksmiths, carpenters, etc.) are roughly equal in rank to this group, and several others, including astrologers, physicians, and launderers, fall into this same category of 'upper polluting castes'. Below them are the Depressed Castes, who form about $15 \%$ of the Hindu population. Until the end of the last century, many were serfs tied to the land they worked; they were debarred from using the public roads. These then are the main Hindu groupings in Malabar: Nambudiri Brahmans, small chieftain castes, 'military' Nayars, inferior or 'nonmilitary' Nayars, upper polluting castes, and Depressed Castes. In addition, there are various small castes of temple servants and some immigrants of castes from other parts of southern India (Miller 1954).

11 Menon described the kavus as the basis of a community of worship in Malabar, where caste inequality was both reinforced and challenged. On the one hand, kavus, which were aligned with specific tharavadus, emphasized the interdependence of castes and mutual obligations by expectations of caste-wise contributions to kavu festivals. On the other hand, the kavus were also centres where a community of worship of castes as equals could be formed. The kavus were characterised by practices such as Thiyya priests, the worship of lower caste victims of upper caste authority, and the sharing of kavu pilgrimages by all castes (Menon 1994, pp. 41-61).

12 Going by the broad parametres laid down by kindred disciplines of anthropology and sociology, it could be safely averred that all of them are tribal people. Though a number of unofficial counts were made between 1821 and 1866, the first Government Census in 1871 returned the tribal population as Badagas-19,476; Todas-693; Kotas-1112; Kurumbas-613; and Irulas-1470 (Cornish 1874, p. 327). 
to the Nilgiris (Hockings 1989, p. 220). ${ }^{13}$ However, another school strongly critiqued this theory of immigration and stated that Mysore and the Nilgiris formed a common land mass. In 1807, the Badagas were reported to be a band of 'rude tribe', who lived in villages called hatties (Buchanan 1807, p. 246; Ouchterlony 1848). Among the Badagas, six distinct sub-sects were found-namely, Wodea, Adhikai, Kanakka, Haruva, Badaga, and Tohrea; and all of them were Shaivites. Barring the converts, all were vegetarians and were generally deemed to be conservative in nature (Stokes 1883, p. 288). Like the Hindus, the Badagas believed in polytheism (Hockings 1989, p. 221).

\section{Narrating the Christian Conversion Driven by the Basel Mission in South India}

The Basel German Evangelical Missionary Society (Nath n.d.; Stenzl 2010) ${ }^{14}$, (in short, the Basel Mission), a Protestant missionary organization, was established at Basel (Raghaviah 2017), ${ }^{15}$ Switzerland, as a child of 18th-century pietism. Pietism was originally a charismatic revolution against the rigid Lutheran church practices and gave birth to the German Christian society for promoting 'Christian truth'. ${ }^{16}$ In India, the Mission started working in the western coast from 1834 onwards with some unique features. Inspired by the Pietist and Calvinist theologies (Prout 1947) ${ }^{17}$, this missionary organization combined its religious activities with industrial activities to such an extent that the latter was seen as essentially religious in nature (Raghaviah 2017). The Basel Mission inspector Blumhardt laid the foundation of this mission in India (Nath n.d.) ${ }^{18}$. The Basel Mission had two objectives in view: preaching the Gospel among the hill tribes and setting up a sanatorium for the missionaries. In India, it was known for its workshops and 'industries' (Stenzl 2010). ${ }^{19}$ Operating in the Malabar and the Nilgiris (regions known for their caste rigidities and exclusions to distorted levels), the Basel Mission, utilising the industrial sphere, challenged the gruesome caste system and its allied rituals. Along with conversion, the Basel Mission ended up in contributing some of the most progressive features which were not present otherwise in India. They started the first modern industries in Malabar, and this beginning led to efforts in spreading basic education and starting orphanages and hospitals, which enabled the converts to develop a better philosophy of life (Raghaviah

13 Tradition mentioned that the Badagas migrated from the plains in the south of Mysore region to the foothills of Nilgiris during the 16th century after the fall of the Vijayanagara dynasty in the battle of Talikota (A.D. 1565) due to the threat caused by the Muslim invasions and famine that occurred in that region (Hockings 1989, p. 220).

14 The Basel Mission was formed in connection with the despotic rule of Napoleon Bonaparte, whose prowess brought fear to Europe in the early days of the 19th century. So, in 1814, Russia, Germany, Austria, and Britain formed a military alliance at Basel and gathered there to attack Napoleon. The French general reacted to this and warned that his canons would blow Basel to bits. It was in this exasperated situation that a group of Christian believers in the allied force met at Basel for a group prayer and took an oath that, should they win against Napoleon, they would form an evangelical mission, conducting missionary activities and charitable work all over the world. Finally, in June 1815, Napoleon was defeated at Waterloo. As a fulfilment of the oath, the believers decided to form a missionary society. Thus, the Basel Evangelical Missionary Society was formed under the Presidentship of Rev. Nicholas van Brunn on 25 September 1815. But it is popularly known as German Basel Evangelical Society because behind the formation, the initiative was taken up by the German soldiers. Gradually, the headquarters shifted from Basel to Germany (Nath n.d.; Stenzl 2010).

15 After the Reformation in Europe, Basel was a centre of the Pietist Movement. This movement had acquired several dimensions. The social activists demanded a total change in the church structure, while another group preferred to remain close to the institutional churches despite hostility. This called for a renewal of church and society - a process often described as 'Church within Church'. A good many of such groups existed in the Wurttemberg province of Germany. The members mainly comprised artisans such as shoemakers, carpenters, blacksmiths, weavers, or people of similar trades who, being financially independent, were not easily intimidated by the city councils and chief pastors (Raghaviah 2017).

16 (Annual Sixty-Seventh Report of the Basel German Evangelical Mission in South West India for the Year 1865, pp. 13-15).

17 Pietism is understood as a reform movement within German Lutheranism begun by Philip Jakob Spener who emphasized individual conversion, 'living faith', and the fruits of faith (Prout 1947).

18 In 1834, with the financial assistance of German Prince William, the Basel Mission sent its first three missionaries, Rev. Samuel Hebich, Rev. John Lehnar, and Rev. Cristoph Grener, to India. The missionaries landed at Calicut on 13 October 1834 and, travelling northwards, commenced the work with their headquarters at Mangalore in South Canara. Consequently, missionary activities were started in three districts of the West Coast comprising Bombay, Karnataka, and Malabar with Mangalore as its headquarters (Nath n.d.).

19 In the 19th century, the German term 'Industrie' (industry) did not mean large-scale production but referred to units of small and cottage industry workshops (Stenzl 2010). 
2017). ${ }^{20}$ Therefore, the object of industrial pursuits was to strengthen the mission cause on the one hand, and benefit the country by creating a class of Christian artisans, mechanics, and tradesmen who could live an honest life and find new sources of revenue on the other (Philip 2000, pp. 215-16).

\subsection{Christianity among the Thiyyas of Malabar}

Christianity in Malabar is almost as old as the Christian era. Roman Catholicism had gained a foothold in Malabar at a much later date, while the Protestant faith was the last to arrive. It was not until 1839 that the Basel Mission established their first outpost in this district. At first, the missionaries' main intention was to train fellow missionaries of other societies which had already started evangelistic work in foreign lands (Kumar 2006, pp. 52-83). The mission stations in Malabar were Cannanore (1841), Tellicherry (1839), Chombala (1849), and Calicut (1842). ${ }^{21}$ Dr. H. Gundert and Rev. Samuel Hebich, the two pioneer missionaries, inaugurated the mission activities in the region. Despite serious oppositions, the open-air sermons ${ }^{22}$ delivered by Samuel Hebich at crowded fairs or festivals, and also the courage with which he triumphantly carried the Gospel, made him an almost 'mythical celebrity' in Malabar). ${ }^{23}$

The Malabar church had a remarkable feature of active participation of members in both pastoral and missionary efforts. However, only fifty could be baptised, many newcomers would continue in their former profession and were able to secure an independent living; while most of the inhabitants realised about the futile nature of observing rituals and austerity. ${ }^{24}$ There had been a movement among the Thiyyas, but their primary motive was not religious. The Thiyyas' main concern was their social standing, as they asked questions like, 'what shall we do in order to rise in the social scale?' instead of 'what shall we do in order to be saved? 25

The influence of Christianity in the region was clear not only from a good number of converts (102 in 1904), but also by violent opposition from the educated classes to propagate a reformed and purified Hinduism, led by the Brahma and the Upasana Samajes, and by the press. Annie Besant, being influenced by Hindu philosophy, bolstered these efforts by delivering addresses in the principal towns of Malabar and won the hearts of many Malayalis and Thiyyas. However, interest for spiritual things among the Thiyya women was very rare. ${ }^{26}$ For example,

at Calicut, "many of my girls" the Bible-woman Thamar remarked, "are convinced that going to the temple is useless." Being asked why they yet go, they

20 During the 19th century, British investments in Malabar were in estates and in trading. Investments in modern industries were made by the Basel Mission. However, the expansion of activities of the Basel Mission came to an abrupt end with the outbreak of the First World War, when the German missionaries became suspects in the eyes of the British administration (Raghaviah 2017).

21 ( Annual Sixty-Sixth Report of the Basel German Evangelical Mission in South West India for the Year 1905, p. 55).

22 'In Chombala, open air preaching was conducted extensively, and the heathen liked those gatherings and wanted for more'. ( Annual Seventy-First Report of the Basel German Evangelical Mission in South West India for the Year 1910, p. 29).

23 'In Cannanore, there were 1300 church members' ( Annual Sixty-Sixth Report of the Basel German Evangelical Mission in South West India for the Year 1905, p. 15).

24 One Hindu woman does not keep fasting any further because she knows that everything will be determined by her attitude and faith towards God and not by external ceremonies. The Cannanore church has a total membership of 1559 . There were 13 additions from the heathen (10 adults and 3 children). Some Christians, of their own accord, engaged in evangelistic work among the heathen. They distributed Malayalam tracts among Hindus and Mohammedans, most of whom took them willingly. The church at Tellicherry had membership of 652, while at Chombala there are 561 Christians; Calicut had 2450 Christians. ( Annual Seventy-First Report of the Basel German Evangelical Mission in South West India for the Year 1910, pp. 31, 58-60).

25 (Annual Sixty-Seventh Report of the Basel German Evangelical Mission in South West India for the Year 1865, pp. 76-77).

26 'An old Tiyar woman told the Bible woman: "stop reading to me, I can't keep God's commandments; therefore, it is better I don't hear them."' ( Annual Sixty-Fifth Report of the Basel German Evangelical Mission in South West India for the Year 1904, pp. 64-70). Hermon, an evangelist at Tellicherry, met with instances showing that faith in witchcraft was in some quarters declining. A woman belonging to the Tiyya caste having attentively listened to Mr. Hermon and his co-workers' preaching, remarked to them: "what you have been saying just now is true; I myself experienced the other day that if one lives in the sight of the Creator invoking Him alone one has nothing to fear from any other being..." ( Annual Seventy-First Report of the Basel German Evangelical Mission in South West India for the Year 1910, p. 27). 
replied, "if we ceased going to the temple you would no longer be allowed to visit us!"27

The largest station of Malabar was Calicut, with 2058 church members, and most of them were engaged in the Tile Factory and Weaving Establishment. More than 100 candidates were ready for baptism, but due to force or intrigue, many lost courage and did not follow through. Efforts to evangelise this part met with resistance from the Muslims, while the educated Hindus reluctantly allowed the missionaries to carry on with their work. $^{28}$ In some cases, prize money was announced to restrict religious conversion, and an opposer, in an instance, offered as much as Rs. 1000 as a reward for bringing a convert back, dead or alive. However, this attempt did not meet with any success ${ }^{29}$ and created a stir among the prospective converts.

Moreover, the missionaries realised that despite conversion, caste Hindus continued to consider the Thiyyas as a 'polluting group' and showed discrimination towards the Christian converts. This social exclusion led to fear among the Thiyyas, whose reasons for embracing Christianity were dubious. The Thiyyas at Tellicherry built a big Shiva temple and collected large sums of money to make it as grand as possible. This act attempted to revive the Hindu religious affiliation of the Thiyyas in the face of Christianity and stop people from alternating their religious faith. ${ }^{30}$

\subsection{Christianity among the Badagas of Nilgiris}

The people of the hills had been predominantly Hindus in the past, and their connections with Hinduism dated back to around the 12th century. It was probably this faith that made them seek shelter in the hills during the alleged Muslim invasion in the Mysore region (Congreve 1847). Thus, the Nilgiris had remained a Hindu-dominated settlement with bleak chances of other religions showing their presence. However, British rule and subsequent European colonisation introduced and established Christianity through their organised missions, churches, Christian colonies, dispensaries, schools, and other institutions. A considerable number of the locals accepted Christian faith to such an extent that by 1900, the ratio of the Christian population was higher in the Nilgiris than any other district in the Madras Presidency (Ilangovan et al. 1999). However, the rate of conversion witnessed fluctuations throughout the 19th and 20th centuries, when occasional instances of conversion in phases happened, which will be discussed shortly.

G.J. Casamajor, a retired judge of the high court, invited the Basel Mission to the region and spent much of his time and energy for the cause of evangelistic and educational work among the Badagas of the Kaity valley (Ilangovan et al. 1999). He also translated the Gospel into Canarese, the language which the Badagas could understand with little difficulty (Hockings 1980, p. 184). On the Nilgiris, the Basel Mission had three stationsKaity (1846), Kotagiri (1867), and Ootacamund (1903)_and from the very outset laid stress on itinerancy which had been invariably recognized as one of the chief duties of the European as well as Indian evangelists. A missionary and a catechist were set apart for the purpose of itinerancy to the Badagas. ${ }^{31}$ The other common method of preaching was open-air preaching. Magic lanterns, a kind of a slide projector, were also used to play upon the curiosity of the Badagas. ${ }^{32}$ By adopting traditional Badaga tunes and singing Christian hymns in Badaga dialect, the Missionaries were able to attract the attention of a large number and disseminated the tenets of Christianity. The Missionaries made it a point to preach at the Hindu festival gatherings in the Coimbatore district to which the Badagas and other hill tribes flocked (Hockings 1980, p. 189). The other means of evangelisation

27 (Annual Seventy-First Report of the Basel German Evangelical Mission in South West India for the Year 1910, p. 31).

28 (Annual Sixty-Sixth Report of the Basel German Evangelical Mission in South West India for the Year 1905, pp. 57-61).

29 ( Annual Thirty-First Report of the Basel German Evangelical Mission in South West India for the Year 1870, p. 45).

30 (Annual Sixty-Seventh Report of the Basel German Evangelical Mission in South West India for the Year 1865, pp. 76-77).

31 (Annual Report of the Basel German Evangelical Mission Society for the Year 1897, p. 52).

32 (Annual Report of the Basel German Evangelical Missionary Society for the Year 1874, p. 41). 
was through establishment of schools and performing other philanthropic activities. The Bible women also participated in social and educational activities of the Mission and went on door-to-door campaigns. ${ }^{33}$

After a brief progress on the Hills, the Basel Mission experienced a bleak period of over a decade when the missionaries, although able to penetrate the hearts of the Badagas, did not succeed in getting even a single convert to Christianity. The Badagas had, on the other hand, successfully thwarted all the attempts of the Missionaries to draw them towards the Mission. ${ }^{34}$

Nevertheless, the missionaries converted a hermit of a low country as early as in 1850 itself at Kaity. However, such conversion was not regarded by the missionaries as 'victory', since they had looked upon the Badagas as a special field of labour. It took nearly twelve years to receive the first Badaga convert. However, not all the Badagas remained adamant. There were a few hopeful cases that preceded the first fruit. The Badagas looked at the missionary activities with suspicion. The Badaga parents refused to send their children to the mission schools ${ }^{35}$. After 13 years of labour, a few Badagas were baptised (Francis 1908, p. 125). Christianity produced contradictory but long-lasting effects in the midst of the local communities of Badagas. Mr. Risch of the Kaity station reported an incident of a departing little boy who lamented to his mother: 'I now go to Jesus and joyfully look forward to be with Him, if you wish to see me again you must become His disciple'. ${ }^{36}$

Education was popularised among the Badagas, and in 1874, the Mission started a school in Kaity valley for the benefit of the Badaga children (Francis 1908, p. 127). ${ }^{37}$ The approaches and partially successful attempts of the Christian Mission in converting the Badagas remarkably went into the ecclesiastical channels in the Hills. ${ }^{38}$ More or less, the

33 Their contribution in carrying the Gospel into the homes of Badagas and to Badaga women who "by their social customs were almost prohibited from hearing the Gospel in any other way" is very substantial and unostentatious. (Annual Report of the Basel German Evangelical Missionary Society for the Year 1894, p. 81). To begin with, the villagers received the Bible women with kindness. Mrs. Lutze, wife of a Missionary relates: "When we come to a village, they quickly sweep some veranda and spread a mat and call: Amma! (mother), Amma! (mother), sit down here and tell us the meaning of the Word". Badaga women on their way to the fields or jungles for collecting firewood voluntarily asked the Bible women to read to them from the Bible to which they readily acceded. At times the doors had to be opened by gifts of medicine and other ministration of love. In the absence of Bible women in some centres, the Missionary ladies visited the Badaga women at their homes. Later on, Badaga menfolk became apprehensive because they feared more and more of their women might become Christian. Hence, they warned the Bible women to go away and read "to the stones but not to their women". Further some of them spread canards about the Bible women, saying that they "distributed a bewitching powder prepared by the Missionaries". So, what began on a promising note, soon ended in a disappointment and the number of Badaga women won over was by no means respectable. ( Annual Fifty-Sixth Report of the Basel German Evangelical Mission in South-West India for the Year 1895, p. 64).

35 One of the best means to prepare hearts for the Gospel message are the schools. For here, the missionaries not only can sow the seed into fresh good human soil, but through the children they often come in contact with the parents. The number of Basel Mission Primary schools for non-Christians in Malabar 23 (including 2 for girls) and Nilgiris 29; lower secondary schools: 6 in Malabar; High School: 3 in Malabar. The sole object of Mission schools- if not conversion- was to instill into the hearts of the young the religious ideas and moral principles taught and followed by Jesus Christ, with the hope that in course of time these ideas and principles will lead to conversion in India. (Annual Sixty-Fifth Report of the Basel German Evangelical Mission in South West India for the Year 1904, pp. 72-74).

36 (Annual Seventy-First Report of the Basel German Evangelical Mission in South West India for the Year 1910, p. 33).

37 The Mission schools suffered from thin enrollment and non-attendance. But when the Badaga parents began to appreciate the value of education, the number of schools in the Badaga villages increased from 3 (in 1847) to 21 (in 1889) and 36 (in 1899). (Francis 1908, p. 127).

38 According to Paul Hockings, the Badaga community as a whole underwent a period of unusual stress for a period of fifty years from 1845 to 1906 . Epidemics frequented in the period, and failures of monsoon led to famine, starvation and death. The Christian mission launched their activities in the same period. It was just a coincidence that Badagas had to meet the religious and temporal stress. However, both were related to one another (Hockings 1980). Mr. Lutze reported an incident: "Betta, a Badaga, broke his caste and joined the Christian openly. This caused a terrible uproar. The heathen Badagas were furious and did their utmost in abusing and insulting both the new converts and the other Christians. His wife was taken away by her relations into the Kundas, and they endeavoured to persuade her to commit suicide by taking opium. But she refused and joined her husband when he came to fetch her... he had been carried away into the jungle by force. Betta was rescued and baptised and received the name of Benjamin. His courageous wife Madi, now Martha, was the first who was baptised during the year under report. The young couple have to suffer a good deal of persecution in the midst of the surrounding heathen. First an attempt was made to expel them from the village by brute force. When that failed, various strategies were resorted to. The Badagas know and openly confess that Christianity, after having once penetrated into a house and village, is contagious. Hence, their violent opposition which would be much less if the Christians left their houses and villages to settle down on the mission premises. But it is for that very reason that we assist our converts who possess houses, lands, and the freedom of village, to maintain those rights and that we insist on their remaining in their houses. Benjamin and Martha have conducted themselves bravely up-to this time, and we trust that our Lord will protect them, keep them fulfilled and soon give them Christian neighbors." ( Annual Fifty-Third Report of the Basel German Evangelical Mission in South West India for the Year 1892, pp. 69-70). 
Badaga Christians emerged as a separate entity and a powerful social group which was recognised by rest of the people in the region.

These positive responses from the Badagas had problems too. Anything 'unnatural' in the Hills was attributed to the spread of Christianity for which both the missionaries and the Christian converts were looked at with suspicion and anger. The outbreak of epidemics (cholera in 1854, smallpox in 1855, and plague in 1877) was blamed on Christian sorcery, ${ }^{39}$ for which the angry Badagas burnt down the Mission's house at Kaity.

In spite of the Badaga hostility, in the wake of the Indian Mutiny, a Badaga, Halaiya by name, embraced Christianity in 1858. He was the first Badaga to do so. As a matter of assistance, during natural calamities and epidemics, some of the Badagas were helped with both money and goods in kind (Hockings 1980, p. 189). ${ }^{40}$ The Badagas, who had criticised the Gospel for quite a long, but changed their attitude over time, and many of them became disciples of Christ as well. The missionaries were almost on terms of friendship with most of them. Mr. Wieland mentioned how well some Badagas were acquainted with the Bible. ${ }^{41}$

\section{Theology of 'Praxis Piety' as a Social Change in Kerala}

Christian missionaries were pioneers in different fields pertaining to the development of modernity in south India, and posing challenges to traditional cultures and societal frameworks. Starting from the first printing press in the 16th century to establishing schools (notably for girls also) for the wide extension of literacy and vocational training, serving medical aid, etc., the major undertakings were carried out by the missionaries (Kent 2004, p. 141). However, missionary undertakings differed by region as well as theologically and ideologically, depending on the nature of that particular organisation.

By the beginning of the 19th century, two missionary societies namely, the Church Missionary Society (CMS) and the London Missionary Society (LMS) were already functioning in Kerala. Both these societies had their headquarters in London. The LMS started its activities in Southern Travancore in 1806, while the CMS started operations in Central Travancore in 1820 (Agur 1903). The missionary enterprise of these two missionary organizations involved establishment of schools and college, printing presses, and seminaries for training of priests and church workers. They also enjoyed some amount of patronage from the government. Therefore, many of the converts could enter into government service at various levels. However, the missional focus of Basel Mission was different from that of the LMS and the CMS. The Mission had both educational an industrial orientation, and many of the missionaries belonged to the class of craftsmen. At the Home Board level, officials were also businessmen and theologians. Therefore, from the very beginning, the Basel Mission began to experiment with crafts, both traditional and modern, because the issue of joblessness cropped among the indigenous Christian converts. The end result was

39 ( Annual Sixty-Seventh Report of the Basel German Evangelical Mission in South West India for the Year 1865).

40 The Waste Land Rules of 1863, The Land Registration Act of 1864, and the Madras Forest Act of 1882 stopped swidden cultivations. It drove many of the Badagas to seek asylum in the Mission. The Mission relieved them of their debts and provided them with some jobs. It led to more and more conversions (Hockings 1980, pp. 185-87).

41 One day, a Badaga came to the wife of one of Christian schoolmasters and asked for food. But she refused because the Badaga was unclean. Therefore, the Badaga replied: "in your Bible it is written: if thine enemy hunger, feed him; if he thirsts, give him drink. Therefore, consider me as your enemy and act in accordance with your Bible." Of course, the woman could not resist this argument (Annual Sixty-Seventh Report of the Basel German Evangelical Mission in South West India for the Year 1865). Mr. Stokes shows a Badaga reform bill looming in the distant future: "the Badagas are not without their reformers. The young men of Yedapullu, a village near Coonoor, have a society called "Yedapullu Sajjana Sangha" (Society of Virtuous People), who in May last deliberated, how the Badaga could be reformed. A paper was drawn up in which a number of proposals are made. The paper was sent round to all Badaga villages to solicit their opinion. The following are some of the proposals: 1. Houses should have at least one large window to let in fresh air. 2. Houses should be kept clean, spitting on the floor of the rooms should be avoided. 3. On Monday (the resting day of the Badagas) all the rooms and courtyards should be smeared with cow dung; the railings should be dusted; the grounded be marked with ornamental white lines; cloth should be washed, and people should take a bath and washing their gods. 4 . The practice of shaving at funerals, of shaving the head of little boys in their first and second year, and of girls between their 12 th year should be given. 5 . Tattooing should be stopped. 6 . Girls should be sent to school. 7. Expensive funerals, playing and dancing at the funerals should be given up. 8. The style of dress of the common should be improved. 9. As a rule Badagas should marry only one wife; in case of marrying a second on account of barrenness of the first, the first should not be sent away. Ten Badagas who indulged in intoxicating drugs or spirits should be induced to give up that practice ( Annual Fifty-Third Report of the Basel German Evangelical Mission in South West India for the Year 1892, pp. 77-78). 
that the Basel Mission established modern tile factories and weaving factories of that time (Raghaviah 1990).

The factories (see Table 1) were modern factories compared to those that existed in Europe during that period. The weaving industry of the Basel Mission produced various types of new products like damask linen counterpanes, towels, trousers, coats, shirts, and jersey and hosiery products. Most of these products were utilised for export purposes. One of the missionaries thought that pottery, a traditional craft in India, might be another promising field for a workshop, and in 1865, he started producing tiles in the 'Basel Mission Tile Works', a very modest workshop with just two workers. The workshop was soon expanded to become a factory that employed 6- workers by 1871 and 131 in 1880. Two years later, the workshops and factories were merged with the Mission Trading Company. Additional tile works were set up, and these factories became the largest of all. The tile industry produced various types of ceramic products like roofing tiles, flooring tiles, salt glazed pipes, ornamental pottery, ceiling tiles, and ventilator tiles (Fischer 1985, pp. 200-15).

Table 1. Industrial enterprises of Basel Mission in Malabar.

\begin{tabular}{cc}
\hline Type of Industry & Number of Units (Including All the Mission Stations) \\
\hline Tile factory & 10 \\
Weaving establishment & 8 \\
Total & 18 \\
\hline
\end{tabular}

Source: ( Annual Sixty-Fifth Report of the Basel German Evangelical Mission in South West India for the Year 1904; Annual Report of the Basel Mission for the Year 1906; Annual Seventy-First Report of the Basel German Evangelical Mission in South West India for the Year 1910).

The ultimate result of all these activities (see, Table 2) was the emergence of a new group of people, including Christian converts as well as non-converts who had come to close proximity with the Basel Mission. These included non-Christian workers in tile and weaving factories, school teachers, and workers in hospitals. These people resided on the fringes of the Malabar society but strongly demonstrated an alternate value base and a corresponding life style (Bourdieu 1979). ${ }^{42}$ The total employment in the Weaving Establishment with a tailoring department at Cannanore and its branches at Chombala and Tellicherry was eight hundred and fifty-two. The Weaving Establishment at Calicut also gave employment to around seven hundred and sixty-four Christian men and women. The Tile works at Puthiyara employed 85 Christian men, 60 Christian women, six inquirers, 95 Hindus, and four Muslims. ${ }^{43}$ The reasons that led to the establishment of workshops included the problem of school leavers, an attempt to bring at least the younger converts away from their current environment, and, in the longer term, the improvement of the prospects of converts from lower castes. Saving money for the mission was also an important consideration. Another reason was that many of the early converts were palmwine tappers who produced and sold alcohol. These activities did not seem to be suitable as a trade for a Christian (Stenzl 2010).

42 The culture of this group differed from the rest of the population. Culture is the system of knowledge shared by a relatively large group of people. It is communicated and shared through symbols, language, values, beliefs and norms. To quote Bourdieu, culture is "a competitive system of social relations functioning according to its own specific logic or rules" (Bourdieu 1979).

43 (Annual Seventieth Report of the Basel German Evangelical Mission in South-West India for 1909, p. 68; Annual Seventy-Second Report of the Basel German Evangelical Mission in South-West India for 1911, p. 79). 
Table 2. Technologies imparted by the Basel Mission industries.

\begin{tabular}{|c|c|c|}
\hline Type of Technology & Impact & Utility \\
\hline Introduction of fly shuttle & $\begin{array}{l}\text { Increases productivity of } \\
\text { weaver from } 50 \text { to } 200 \text { percent } \\
\text { depending on the width of } \\
\text { cloth }\end{array}$ & Adopted \\
\hline Use of frame looms & $\begin{array}{l}\text { Weaving cloth of greater weft } \\
\text { in comparison with pit loom }\end{array}$ & Adopted \\
\hline $\begin{array}{l}\text { Introduction of Jacquard } \\
\text { looms }\end{array}$ & Weaving a variety of designs & Adopted \\
\hline Use of chemical dyes & $\begin{array}{c}\text { Yarn can be dyed to a wide } \\
\text { variety of colour combinations }\end{array}$ & Adopted \\
\hline $\begin{array}{l}\text { Development of 'Khakhi' dye } \\
\text { from the bark of a tree }\end{array}$ & $\begin{array}{l}\text { This colour came to be } \\
\text { adopted in uniform for army }\end{array}$ & $\begin{array}{l}\text { New units did not make any } \\
\text { inventions in dyeing }\end{array}$ \\
\hline Establishment of a dye house & $\begin{array}{l}\text { Specialization, vertical } \\
\text { integration of weaving }\end{array}$ & $\begin{array}{l}\text { In Kannur region specialized } \\
\text { units for dyeing did come up }\end{array}$ \\
\hline $\begin{array}{l}\text { Introduction of machine } \\
\text { power for handloom industry } \\
\text { for spool winding, dyeing, etc }\end{array}$ & $\begin{array}{l}\text { Improvement in the } \\
\text { productivity of handloom }\end{array}$ & $\begin{array}{l}\text { Only one or two large units } \\
\text { used machine power }\end{array}$ \\
\hline Introduction of power loom & $\begin{array}{l}\text { Large scale manufacture of } \\
\text { standard designs }\end{array}$ & $\begin{array}{l}\text { One or two large units } \\
\text { introduced power loom }\end{array}$ \\
\hline
\end{tabular}

One of the best means to prepare hearts for the Gospel message were the schools. For here, the missionaries not only could sow the seed into fresh good human soil, but through the children, they often came in contact with the parents. The number of Basel Mission Primary schools for non-Christians in Malabar was 23 (including two for girls) and in Nilgiris was 29; lower secondary and high schools: six and three in Malabar respectively.

Dr. Gundert, a brilliant scholar of the Tubingen University, gave his life to the literary and educational work of the mission. He was the author of the first Standard Dictionary and Grammar in Malayalam apart from the many text books in history, geography, and other subjects for the mission. He had contributed greatly to cultural efflorescence (Thomssen 1905, p. 15). In 1890, Malabar got its own Theological Seminary at Nettur. Since then, the workers for Canara, S. Mahratta, Coorg, and the Nilgiris have been trained at the Mangalore Seminary and workers for Malabar have received training at the Nettur Seminary. ${ }^{44}$ In addition to the educational institutions, the mission also maintained two orphanages and four hospitals for the benefit of the society.

Rev. J. Josenhans, principal of the college for missionaries at Basel and General Secretary of the Mission, had put forward certain regulations which guided the missionaries. They even compiled those to a short compendium of church rules. In 1851, there were four congregations with a membership of about fifty in Malabar. ${ }^{45}$ By 1913, it had grown to eight stations and about 40 outstations, with a membership of nearly seven thousand and six hundred. This progress was not, however, confined to numerical strength. During these six decades, the church had been gradually advancing towards the attainment of both selfsupport and self-government. ${ }^{46}$ To enable each church to look after its own spiritual want, he also created church funds, which he endowed with fields and coconut gardens, formerly belonging to the Mission, and imposed church taxes and encouraged charity. ${ }^{47}$ However, for the Badagas, material considerations had played a greater part in effecting conversions.

44 ( Annual Sixty-Seventh Report of the Basel German Evangelical Mission in South West India for the Year 1865, pp. 35-40).

45 (Annual Twelfth Report of the Basel Evangelical Mission for 1851, p. 18).

46 (Annual Forty-Fifth Report of the Basel German Evangelical Mission in South Western India, 1884, pp. 17-20).

47 ( Annual Thirty-Third Report of the Basel Evangelical Mission in South Western India for 1872, p. 22) 
They went 'to the Mission house more often for temporal than spiritual aid' ${ }^{48}$ Had the Mission advanced loans or monetary help to all such Badagas who came to the Mission, the number of converts would have considerably increased. However, the missionaries did not take advantage of such instances for engineering mass conversion, rather, steadily aimed at preparing the Badaga Christians to be self-reliant and independent of the missionaries in things pertaining to their livelihood. This attitude of the missionaries grew not due to sympathy 'but by principle'. ${ }^{49}$ The mercantile establishment in Calicut formed a separate branch, carried on from funds altogether distinct from the Mission funds. 'Money-making' had never been the chief purpose of those establishments; one of the main motives was the training of natives for honest trade.$^{50}$ The object of the Basel Mission mercantile and industrial establishments was to assist the Christians whom the Mission had employed, to acquire after some time own houses and compounds. For this purpose, 'Saving and Loan Funds' had been founded in connection with the workshops. The beneficial effects of these institutions on the temporal condition of the Christians and their moral and religious life could not be underrated. ${ }^{51}$ Therefore, trade and industry in the Basel Mission developed not from an economic strategy, but in response to the needs to solve the local problems.

The Basel Mission which came to Malabar and the Nilgiris with the avowed aim of Christianisation, however, could not achieve the degree of success it wanted, but its labours produced far-reaching results in other walks of life. The impact of their work, in areas of education, social protection, preservation and protection of native art forms, and creative output and public health, was of greater magnitude. The Basel missionaries and their culture created an alternative and competitive network of social relations and attempted to change the traditional culture of the region.

Caste is one of the oldest institutions in India. It is believed that one is born into a caste and dies as the member of the same caste. Therefore, mobility in caste, unlike class, is not a feasible option in a traditional caste society. Even culture, in terms of dress, food habits, personal names, etc., is determined by the respective caste to which one belongs (Dirks 2001; Ghurye 1950; Béteille 1965; Srinivas 1962; Olcott 1944). In this context, the Basel Mission attempted to demolish the notion of caste among the converts. The missionaries could secure converts from high, middle, and lower castes and simultaneously embraced the notion of 'purity and pollution' attached to the lower caste (Dumont 1980). An individual, after conversion to Christianity, used to lose his job, for which the Basel Mission started with social engineering among the converts who left their traditional occupations and learnt new activities. New lines of employment included working in the weaving and tile factories, which involved association with machines. Other opportunities included work at schools and hospitals. So, these vocational professions had no room for caste differentiation (Raghaviah 2017). The main aim of these establishments was to teach the converts an honest labour and trade, to provide them the possibility to earn a livelihood without asking for alms, and thus have a sedentary life. The different managers of these establishments exercised particular supervision over the moral conduct of their employees and tried to advance them in religion as well. They acted as assistants to the pastoral work. ${ }^{52}$

48 (Annual Fifty-Sixth Report of the Basel German Evangelical Mission in South-West India for the Year 1895, pp. 58-59).

49 (Annual Report of the Basel German Evangelical Mission in South-West India for the Year 1880, p. 36).

50 (Annual Thirty-Sixth Report of the Basel German Evangelical Mission in South-West India for the Year 1875, p. 49).

51 Mr. Schonthal writes, I have much joy in stating that a number of our Christian weavers have again been enabled to improve their temporal condition by acquiring houses which they may now call their own in the fullest sense of the word. Some of them have completely repaid the loans they had some years ago received for this purpose from the funds of the Establishments, and now continue every month to deposit part of their earnings into the Savings fund. A weaver who lately got his house free of debt, has since been able to save Rs.125. another who received a loan of Rs. 500, has already repaid Rs. 250 by instalments. Another has deposited with me Rs.461, all of which he has saved from his earnings. A weaver of Tellicherry, who was apprenticed here, have saved nearly Rs.100 since April 1893. Lately he asked me for the sum in order to build a house. Of the weavers at Tellicherry, 14 at least possess houses of their own, and only two of them owe still part of the purchase-money. As a matter of fact, it takes a long time until such changes in the temporal condition of our Christian are affected, but what we have attained for the present is more than we ever expected. ( Annual Fifty-Sixth Report of the Basel German Evangelical Mission in South-West India for the Year 1895, p. 95). 
In Kerala, there was no concept of specific working hours, and it stretched to an extent of personal deprivation. Before starting factories, the Basel Mission had tried to introduce modern crafts like watch making and repairing which would develop a sense of time in people. However, due to lack of local demand, this endeavour did not meet with much success. The factories established by the Mission did instilled a sense of discipline with respect to time. Every activity in the factories followed a specific schedule, and the workers had to adapt themselves to the new system of 'work-related sense of self' (Raghaviah $2017)^{53}$. This changed the attitude towards work and shows how the concept of 'praxis piety' determined each undertaking of the Basel Mission.

In the field of science, the Basel Missionaries encountered a different atmosphere in India. Starting from identifying good clay and diagnosing diseases to using horoscopes, all were deemed as 'scientific activities.' It was George Plebst, who was the first to establish a tile factory at Mangalore and was supposed to have used the expertise of a local potter in identifying the suitable clay for making tiles which was then tested in laboratories of Switzerland, only to find that those clay samples were feldspar materials. This meant that, in the later stages, clay was scientifically tested for its durability and strength. Traditional potters also came to know of these qualities of feldspar a little differently, although they failed to classify it (Raghaviah 2017). ${ }^{54}$ Still, this transition of scientific knowledge was an important contribution of the Basel missionaries.

During the work of Basel Mission, the indigenous population also received instructions from the Roman Catholics thrice a day and had to undergo all kinds of spiritual exercises before baptism. This generosity attracted masses, but it did last for long. After being baptised, the new converts were not kept under supervision, and had to find a livelihood of their own. If they failed to do so, the converted Christians were turned into beggars. On Christmas, around four hundred and thirty beggars came to Mr. Ritter's bungalow and about three hundred of them were Roman Catholics. In the Report of the Fourth Decennial Indian Missionary Conference held in Madras 1902.

there are three great evils which exist more or less in the churches of certain (if not all) districts of India and Ceylon which are great hindrances to the spread of Christ's Kingdom, viz: caste, debt, and intemperance. These must be purged away before the churches can fulfil their high vocation.

However, these criticisms could not be applied for the Basel Mission in its entirety. Caste spirit had never found a home in Basel Mission churches, and in reality, there was no caste problem in the Mission. ${ }^{55}$

The convert or candidate for baptism was the one taking the initiative. Crucially, the mission demanded that converts remove all visible signs of caste and cease to observe caste rules. This requirement too was seen as a test of applicants' sincerity and as a condition for the mission's support. The converts were also expected to disassociate themselves from non-Christians. Therefore, conversion clearly involved much more complex reasons and consequences than the conventional representation of the convert as a hapless victim of social and economic exclusion. Marginalisation and exclusion of converts did happen,

53 All the factory workers lived within a radius of one or one and a half kilometers from the factory site. Factories used to have powerful steam-operated whistles that were audible from that distance. There used to be two whistles to alert the workers to prepare and report for duty on time. The factories, schools, and hospitals established by the Basel Mission operated on the precision of time. In factories and schools, there were regular breaks from work. The concept of Sunday as a holiday is taken from the Jewish concept of Sabbath. It says that God took six days to create Heaven and Earth and rested on the seventh day. Industrial societies clearly distinguished work from leisure or rest. Among the converts, Sunday was a day of rest, and the worker's family was not even permitted to do routine family chores like washing. Industrial work in factories was both monotonous and hard. Resting at regular intervals enabled them to keep up the efficiency of work (Raghaviah 2017).

54 Western empirical science is backed by the knowledge of basic disciplines like mathematics, physics, and chemistry. Basel missionaries and technocrats were products of the post-Industrial Revolution era. They understood a machine from a very different perspective. They understood what existed in India was in the form of craft. The Report of the Industrial Commission of the Basel Mission for the year 1856 expresses these aspects: 'We should not ignore the fact that a converted Hindu is not by far a European, not to forget that our civilization created by the Gospel and existing since one and a half millennia is a gift of a special divine grace, which confers on us also manufacturing skills of an unusually great advantage' (Raghaviah 2017).

55 (Annual Sixty-Seventh Report of the Basel German Evangelical Mission in South West India for the Year 1865, pp. 35-40). 
but it was in a sense of a mutual exclusion for which, conversion was not just a personal, spiritual, or emotional experience and transformation. Whether it was seen as an act of contestation, emancipation, or a search for social mobility, it had wider repercussions. For the converts, conversion meant both the 'deracination from a familiar world to which they had once belonged' and integration into a new community with its own stringent rules. The new allegiance and the severing of ties with family and community changed both the converts and the community they left (Oddie 1977). The mission's strategies of forming communities that were as far as possible detached from previous lifestyles and religious observances, and also independent from the society surrounding them, were not just responses to but triggered by local resistance. Similar to the aspirations of pietist communities in Württemberg, the Basel Mission attempted to build 'purely' Christian communities, an ideal that was central to their mission. Such communities were thought to be essential to ensure that conversions were durable and self-sufficient. The endogamous Christian communities, where many worked for the mission in similar jobs, formed a somewhat recognisable pattern in their host society, and all these changes were outcomes of the 'praxis practice' model (Kaufmann 1981).

\section{Conclusions}

The intermingling of theology, mission, and history has been a dominant feature in the history of Christian conversion movement. In a general sense, the history of theology refers to the 'discourse on God' which loops in 'systematic theology' that formulates rational and coherent accounts of the doctrines of Christian faith and builds on biblical disciplines and church history. History of Christian missions, on the other hand, traces the expansion of Christianity to the colonial world and assesses its position as a major religious force worldwide, championing Christianity over 'infidelity'. It does not overlook the specific methods undertaken by missionaries. Finally, the history of Christianity refers to the Christian religion, Christendom. Each church denomination is founded on the basis of these principles which play a sine qua non role in promoting different approaches in propagating Christianity (Frykenberg 2003; Young 2009; Robinson and Clarke 2003). Most of the 19th century Protestant missions were organised under the aegis of religious revivalism, and the Evangelical movement which started with a moral focus ended with a focus on performing social responsibility in the respective regions (Chaudhuri 2012, p. 89). ${ }^{56}$ In due course, the missionary objectives and approaches changed in accordance to the aspirations of the converts (Clarke 2003, p. 339).

In this study, both the Thiyyas and the Badagas responded to the Basel missionaries as active participants due to sufferings related to their low social standing, economic backwardness, and agelong sub-ordination and deprivation under the upper caste Hindus, and later by the European colonisers. For them, changing the religious affiliation was a mode of protest against oppressive dominant group, and without their willingness, conversion would not had taken place (Mosse 2010; Robinson 1998; Caplan 1987). It is undeniable that material benefits were the driving force behind conversion, yet a change in the 'real-self' resulted in adaptation of new lifestyle and culture, from religion to vocational training, that was introduced by the Basel missionaries, which ultimately led to an 'enculturation' in the region (Michael 2015, pp. 5-6). Therefore, conversion for these groups was a combination of both socio-psychological and socio-historical process. Although the story of Christian conversion had been a constant process of 'push and pull' which had its expression in both religious and cultural migration, there were 'mass movements' among the outcastes and the adivasis (tribal). However, it will be quite an exaggeration to state that the converts received welcoming responses from both their society and the Europeans and

56 The Evangelical movement, which started in 18th century, became more active during the 19th century. Its focus shifted from a predominantly moral movement to become a social movement as a response to the impact of the Industrial Revolution on British society, when the urban working class faced great destitution; the Evangelicals became concerned in ameliorating the miseries of the underprivileged sections of the society (Chaudhuri 2012, p. 89). 
received equal treatment from the upper-caste Christians and 'born Christians ${ }^{\prime 57}$ because being a Christian or a Hindu was not just a matter of personal identity but had social and institutional implications as well (Amaladoss 2011, pp. 135-54). Conversion altered the demographic equation in a society and also challenged the religious doctrines and practices of the upper caste community (Viswanathan 1998). So, for the converts, it was an intolerable predicament of entering into a 'social and cultural no-man's land' (Copley 2000, p. 187). Moreover, conversion involved 'civil death' by severing connections with the relatives who chose to remain non-converts. Therefore, religious conversion could be interpreted in a complex 'index of material and social conflict' (Viswanathan 1998, p. 76). Also, starting from a historical context, then moving through critical circumstances, and finally ending up in witnessing both positive and negative consequences, the conversion experiences among the Thiyyas and the Badagas fit well into the Seven-Stage Model.

Unlike the Roman Catholics, who from the beginning regarded the caste structure as the basis of the society, had no intention in detaching the converts from the social context, and worked among the high castes making their mission work easier (Forrester 1980; Bugge 1994), the Protestant missionaries with a strong Pietistic background (Frykenberg 2008) arrived in South India for 'missionizing (of) the "heathens" seriously by teaching and educating the local people from various caste communities' (Jeremiah 2020, p. 24). The Basel Mission operated in Kerala with both theological and missiological ideologies within the broader framework of active piety which aimed at providing livelihood (an attempt for which they had been labelled as a 'towel mission'), and making the converts independent. This motive manifested with the establishment of industrial 'prototype'. Because individual preaching was a part of the 'systematic theology', the Basel missionaries gave much importance to it, for which they had to be adept in local languages. Considering the social position and plight of the lower castes, the Mission aimed in training indigenous workers by establishing colleges and seminaries and setting up factories for heuristic purposes, which ultimately evolved and developed into a full-fledged business sector over time, providing a livelihood for a number of people. In the caste society where subordination depended on hierarchy, the Basel missionaries provided these outcastes with an opportunity to experience an alternative sphere of modernity and equality in the world of Christ, which was central to the theme of 'praxis piety' (Bugge 1994, p. 93; Menon 2002). Some might argue that this attempt to homogenise the indigenous people in terms of religion and culture, ultimately destroyed the traditional legacy, history of the people, and affected the social equation, which led to local resistances from the non-converts (Etherington 1976). Nevertheless, the pros and cons of religious conversion is an unending debatable issue. But, because the concept of 'national park' for retaining the indigeneity of the people, as suggested by Verrier Elwin $(1958,1964)$, is a bit anachronistic; therefore, for the advancement of the marginalised section per se, introduction of 'modern' amenities was necessary to cope with the trends of 'mainstream civilisation'. Therefore, the core theory of 'practice praxis' and the notion of progress and development had a larger impact on both the individual and the society which ultimately led Kerala to emerge as a 'model state' in India (Mohan 2015; Desai 2005).

Funding: This research received no external funding.

Acknowledgments: I am indebted to Raj Sekhar Basu for introducing me to this genre in history writing, and his constant encouragement made me write this article for the journal. Also, my heartfelt gratitude to Carlos F. Cardoza-Orlandi and the reviewers whose comments have not only helped to improve my article, but also came as a learning experience to me.

57 One cannot bypass the fact that casteism still prevails within the Christian churches of India. A study conducted in Tamil Nadu revealed the discriminatory practices in the Catholic and Protestant churches starting from construction of chapels for non-Dalits and Dalits, to separate sitting arrangements within the same chapel, and barring the Dalit Christians from participating in certain occasions like the Corpus Christi procession. Moreover, the Dalit Christians were divided among themselves in different subsects like the Hindus and observed caste discrimination against one another (Raj 1992; Augustine 1984; Jeremiah 2020, pp. 21-30). 
Conflicts of Interest: The author declares no conflict of interest.

\section{References}

Abraham, Janaki. 2010. Wedding Videos in North Kerala: Technologies, Rituals, and Ideas about Love and Conjugality. Visual Anthropology Review 26: 116-27. [CrossRef]

Agur, Christian Masillamani. 1903. Church History of Travancore. Madras: SPG Press.

Alexander, K. C. 1980. Emergence of Peasant Organisations in South India. Economic and Political Weekly 15: 72-84.

Amaladoss, Michael. 2011. Hindu and Christian: Conflict or Challenge? In Indian and Christian: Changing Identities in Modern India. Edited by Cornelis Bennema and Paul Joshua Bhakiaraj. Bangalore: SAIACS Press.

Annual Fifty-Sixth Report of the Basel German Evangelical Mission in South-West India for the Year 1895. 1896. Mangalore: Basel Mission Press. Annual Fifty-Third Report of the Basel German Evangelical Mission in South West India for the Year 1892. 1893. Mangalore: Basel Mission Press. Annual Forty-Fifth Report of the Basel German Evangelical Mission in South Western India, 1884. 1885. Mangalore: Basel Mission Press. Annual Report of the Basel German Evangelical Mission in South-West India for the Year 1880. 1881. Mangalore: Basel Mission Press. Annual Report of the Basel German Evangelical Mission Society for the Year 1897. 1898. Mangalore: Basel Mission Press.

Annual Report of the Basel German Evangelical Missionary Society for the Year 1874. 1875. Mangalore: Basel Mission Press.

Annual Report of the Basel German Evangelical Missionary Society for the Year 1894. 1875. Mangalore: Basel Mission Press.

Annual Report of the Basel Mission for the Year 1906. 1907. Mangalore: Basel Mission Press.

Annual Seventieth Report of the Basel German Evangelical Mission in South-West India for 1909. 1910. Mangalore: Basel Mission Press.

Annual Seventy-First Report of the Basel German Evangelical Mission in South West India for the Year 1910. 1911. Mangalore: Basel Mission Press.

Annual Seventy-Second Report of the Basel German Evangelical Mission in South-West India for 1911. 1912. Mangalore: Basel Mission Press. Annual Sixty-Fifth Report of the Basel German Evangelical Mission in South West India for the Year 1904. 1905. Mangalore: Basel Mission Press. Annual Sixty-First Report of the Basel German Evangelical Mission in South West India for the Year 1900. 1901. Mangalore: Basel Mission Press. Annual Sixty-Seventh Report of the Basel German Evangelical Mission in South West India for the Year 1865. 1866. Mangalore: Basel Mission Press.

Annual Sixty-Sixth Report of the Basel German Evangelical Mission in South West India for the Year 1905. 1906. Mangalore: Basel Mission Press.

Annual Thirty-First Report of the Basel German Evangelical Mission in South West India for the Year 1870. 1871. Mangalore: Basel Mission Press.

Annual Thirty-Sixth Report of the Basel German Evangelical Mission in South-West India for the Year 1875. 1876. Mangalore: Basel Mission Press.

Annual Thirty-Third Report of the Basel Evangelical Mission in South Western India for 1872. 1873. Mangalore: Basel Mission Press.

Annual Twelfth Report of the Basel Evangelical Mission for 1851. 1852. Mangalore: Basel Mission Press.

Augustine, P. A. 1984. Andhra Church: The Caste Factors. Jaipur: St. Xavier School.

Basu, Raj Sekhar. 2011. Nandanar's Children: The Paraiyans' Tryst with Destiny, Tamil Nadu 1850-1956. New Delhi: Sage.

Bayly, Susan. 1989. Saints, Goddesses and Kings: Muslims and Christians in South Indian Society, 1700-1900. Cambridge: Cambridge University Press.

Beidelman, T. O. 1982. Colonial Evangelism: A Socio-Historical Study of an East African Mission at Grassroots. Bloomington: Indiana University.

Béteille, André. 1965. Caste, Class and Power: Changing Patterns of Stratification in Tanjore Village. California: University of California Press.

Bourdieu, Pierre. 1979. La Distinction: Critique Sociale du Jugemnt. Paris: Les Editions de Minuit, Translated by Richard Nice. As Distinction: A Social Critique of the Judgement of Taste. Available online: https://monoskop.org/images/e/e0/Pierre_Bourdieu_ Distinction_A_Social_Critique_of_the_Judgement_of_Taste_1984.pdf (accessed on 21 October 2020).

Buchanan, Francis. 1807. A Journey from Madras through the Countries of Mysore, Canara and Malabar. London: W. Bulmer and Co.

Bugge, Henriette. 1994. Mission and Tamil Society: Social and Religious Change in South India (1840-1900). Surrey: Curzon Press Ltd.

Caplan, Lionel. 1987. Studies in Religious Fundamentalism. Albany: State University of New York Press.

Cederlöf, Gunnel. 1997. Bonds Lost: Subordination, Conflict and Mobilisation in Rural South India c.1900-1970. New Delhi: Rajkamal Electric Press.

Cederlöf, Gunnel. 2002. Narratives of Rights: Codifying People and Land in Early Nineteenth-Century Nilgiris. Environment and History 8: 319-62. [CrossRef]

Chand, Subhas, R. Raghupathy, and Madhu Madegowda. 2009. Dynamics of agrarian structure of Nilgiris district of Tamil Nadu and its implications. Indian Journal of Soil Conservation 37: 217-23.

Chaudhuri, Tripti. 2012. Evangelical or Imperial? Re-Examining the Missionary Agenda among the Santhals, 1855-1885. In Narratives from the Margins: Aspects of Adivasi History in India. Edited by Sanjukta Das Gupta and Raj Sekhar Basu. Delhi: Primus Books.

Clarke, Sathianathan. 2003. Conversion to Christianity in Tamil Nadu: Conscious and Constitutive Community Mobilisation Towards a Different Symbolic World Vision. In Religious Conversion in India: Modes, Motivations, and Meanings. Edited by Rowena Robinson and Sathianathan Clarke. New Delhi: Oxford University Press.

Comaroff, John L., and Jean Comaroff. 2001. On Personhood: Anthropological Perspectives from Africa. Social Identities 7: $267-83$. [CrossRef] 
Congreve, Captain H. 1847. The Antiquities of the Neilgherry Hills, Including an Inquiry into the Descent of Taauthawars or Tadars. Madras Journal of Literature and Science XIV: 131.

Copley, Antony. 2000. Religions in Conflict: Ideology, Cultural Contact and Conversion in Late Colonial India. Delhi: Oxford University Press. First Published 1997.

Cornish, William R. 1874. Report on the Census of Madras Presidency 1871. Madras: E. Keys, Government Gazette Press.

Desai, Manali. 2005. Indirect British Rule, State Formation, and Welfarism in Kerala, India, 1860-1957. Social Science History 29: 457-88.

Dhanagare, Dattatreya Narayan. 1977. Agrarian Conflict, Religion and Politics: The Moplah Rebellions in Malabar in the Nineteenth and Early Twentieth Centuries. Past E Present Society 74: 112-41.

Dirks, Nicholas B. 2001. Castes of Mind: Colonialism and the Making of Modern India. Princeton: Princeton University Press.

Dumont, Louis. 1980. Homo hierarchicus: The Caste System and Its Implications. Chicago: University of Chicago Press.

Elwin, Verrier. 1958. Leaves from the Jungle: Life in a Gond Village. London: Oxford University Press.

Elwin, Verrier. 1964. The Tribal World of Verrier Elwin: An Autobiography. London: Oxford University Press.

Etherington, Norman A. 1976. Mission Station Melting Pots as a Factor in the Rise of South African Black Nationalism. The International Journal of African Historical Studies 9: 592-605. [CrossRef]

Fischer, Rudolf. 1985. Mission and Modernisation: The Basel Mission Factories as Agencies of Social Change. In Wholeness in Christ: The Legacy of the Basel Mission in India. Edited by Godwin Shiri. Mangalore: Karnataka Theological Research Institute.

Forrester, Duncan B. 1977. The Depressed Classes in Conversion to Christianity. In Religion in South Asia: Religious and Conversion Movements in South Asia in Medieval and Modern Times. Edited by Geoffrey A. Oddie. Columbia: South Asia Books.

Forrester, Duncan B. 1980. Caste and Christianity: Attitudes and Policies on Caste of Anglo-Saxon Protestant Missions in India. London: Curzon Press.

Francis, Walter. 1908. Madras District Gazetteers: The Nilgiris. Madras: The Government Press.

Frykenberg, Robert Eric, ed. 2003. Christians and Missionaries in India: Cross-Cultural Communication Since 1500, with Special Reference to Caste, Conversion, and Colonialism. Michigan and New York: W.B. Eerdmans Pub.

Frykenberg, Robert Eric. 2008. Christianity in India: From Beginnings to the Present. Oxford: Oxford University Press.

Ghurye, Govind Sadashiv. 1950. Caste and Race in India. Bombay: Popular Prakashan.

Gladstone, John Wilson. 1984. Protestant Christianity and People's Movements in Kerala: A Study of Christian Mass Movements in Relation to Neo-Hindu Socio-Religious Movements in Kerala, 1850-1936. Trivandrum: Seminary Publications.

Gopalakrishnan, M., ed. 1995. Gazetteer of India Tamil Nadu State: The Nilgiris District; Madras: Government of Tamil Nadu.

Hardgrave, Robert L. 1969. The Nadars of Tamilnad: The Political Culture of a Community in Change. Berkeley and Los Angeles: University of California Press.

Harding, Christopher. 2008. Religious Transformations in South Asia: The Meanings of Conversion in Colonial Punjab. Oxford: Oxford University Press.

Hedlund, Roger E. 2016. Indian Christianity: An Alternate Reading. New Delhi: Christian World Imprints.

Hefner, Robert W. 1993. World Building and the Rationality of Conversion. In Conversion to Christianity: Historical and Anthropological Perspectives on a Great Transformation. Edited by Robert W. Hefner. Los Angeles and Oxford: University of California Press.

Hobson, John. 1902. Imperialism: A Study. New York: James Pott and Co.

Hockings, Paul. 1980. Ancient Hindu Refugees Badaga Social History 1550-1975. New Delhi: Vikas Publishing House Pvt.

Hockings, Paul. 1989. The Badagas. In Blue Mountains: The Ethnography and Bio-Geographies of a South Indian Region. Edited by Paul Hockings. Delhi: Oxford University Press.

Horton, Robin. 1971. African Conversion. Africa 41: 85-107. [CrossRef]

Ilangovan, T., A. Perumal, and George James Casamajor. 1999. An Ambassador of Christianity on the Nilgiris. Udhagamandalam: The Casamajor Trust.

Jeremiah, Anderson H. M. 2020. Community and Worldview among Paraiyars of South India: 'Lived' Religion. New Delhi: Bloomsbury India.

Karat, Prakash. 1973. Agrarian Relations in Malabar: 1925 to 1948. Part One. Social Scientist 2: 24-37. [CrossRef]

Kaufmann, S. B. 1981. A Christian Caste in Hindu Society: Religious Leadership and Social Conflict among the Paravas of Southern Tamil Nadu. Modern Asian Studies 15: 203-34. [CrossRef]

Kent, Eliza F. 2004. Converting Women: Gender and Protestant Christianity in Colonial South India. Oxford: Oxford University Press.

Kodoth, Praveena. 2001. Courting Legitimacy or Delegitimizing Custom? Sexuality, Sambandham, and Marriage Reform in Late Nineteenth-Century Malabar. Modern Asian Studies 35: 349-84. [PubMed]

Kooiman, Dick. 1989. Conversion and Social Equality in India: The London Missionary Society in South Travancore in the Nineteenth Century. New Delhi: Manohar Publications.

Kumar, Fedrick Sunil. 2006. The Basel Mission and Social Change-Malabar and South Canara: A Case Study (1830-1956). Ph.D. thesis, University of Calicut, Calicut, India. Available online: https://shodhganga.inflibnet.ac.in/bitstream/10603/30037/10/10_ chapter\%203.pdf (accessed on 16 October 2020).

Kumaradoss, Y. Vincent. 2007. Robert Caldwell: A Scholar-Missionary in Colonial South India. Delhi: Cambridge Press.

Logan, William. 1906. Manual of Malabar District; Madras: Government Press.

Masondo, Sibusiso. 2015. Conception of Conversion among African Christians in South Africa. Journal for the Study of Religion 28: 87-112. 
Menon, Ajit, Christelle Hinnewinkel, Sylvie Guillerme, Marie Laval, and Claude Garcia. 2008. 'Forests', Agrarian landscapes and public policies in the Central Western Ghats of South India. Paper presented at the 12th Biennial Conference of the International Association for the Study of the Commons Governing Shared Resources: Connecting local Experience to Global Challenges, Cheltenham, UK, July 14-18; Available online: https:/ / halshs.archives-ouvertes.fr/halshs-01022349/document (accessed on 23 October 2020).

Menon, Dilip M. 1994. Caste, Nationalism, and Communism in South India: Malabar, 1900-1948. Cambridge: Cambridge University Press. Menon, Dilip M. 2002. Religion and Colonial Modernity: Rethinking Belief and Identity. Economic and Political Weekly 37: $1662-67$.

Menon, K. P. Padmanabha. 1933. History of Kerala. Cochin: Government Press, vol. III.

Metuh, Emefie Ikenga. 1987. The Shattered Microcosm: A Critical Survey of Conversion in Africa. In Religion, Development and African Identity. Edited by Kirsten Holst Petersen. Uppsala: Scandinavian Institute of African Studies.

Michael, S. M. 2015. Christianity and Cultures: Anthropological Insights for Christian Mission in India. Delhi: ISPCK.

Miller, Eric J. 1954. Caste and Territory in Malabar. American Anthropologist 56: 410-20. [CrossRef]

Mohan, P. Sanal. 2015. Modernity of Slavery: Struggles Against Caste Inequality in Colonial Kerala. New Delhi: Oxford University Press.

Mosse, David. 2010. The Catholic Church and Dalit Christian Activism in Contemporary Tamil Nadu. In Margins of Faith: Dalit and Tribal Christianity in India. Edited by Rowena Robinson and Joseph Marianus Kujur. New Delhi: Sage.

Mosse, David. 2012. The Saint in the Banyan Tree: Christianity and Caste Society in India. Berkeley: University of California Press.

Nath, Baiju K. n.d. Brief History of the Basel Evangelical Mission in Malabar. Calicut: University of Calicut, Available online: https: //www.academia.edu/35615261/Brief_History_of_the_Basel_Evangelical_Mission_in_Malabar (accessed on 6 March 2020).

Nesamony, Sam. 2016. Missionaries, Literacy and Intellectual Consciousness in South Travancore. Proceedings of the Indian History Congress 77: 651-64.

Oddie, Geoffrey A., ed. 1977. Religion in South Asia: Religious Conversion and Revival Movements in South Asia in Medieval and Modern Times. Columbia: South Asia Books.

Olcott, Mason. 1944. The Caste System of India. American Sociological Review 9: 648-57. [CrossRef]

Ouchterlony, J. 1848. Geographical and Statistical Memoir of a survey of the Neilgherry Mountains. The Madras Journal of Literature and Science XV: 49.

Padhmanabhamenon, K. P. 1983. History of Kerala, Vol. 2. New Delhi: Asian Educational Services.

Panikkar, K. M. 1953. Asia under Western Dominance: A Survey of the Vasco Da Gama Epoch of Asian History, 1478-1945. London: George Allen and Unwin Ltd.

Philip, Alexander. 2000. Selected Indigenous Church Movements in Kerala: A Study. In Christianity is Indian: The Emergence of an Indigenous Community. Edited by Roger E. Hedlund. Delhi: ISPCK.

Pillai, E. K. 1970. Studies in Kerala History. Kottayam: National Book Stall.

Porter, Andrew. 2004. Religion versus Empire? British Protestant Missionaries and Overseas Expansion, 1700-1914. Manchester: Manchester University Press.

Prout, William Cardwell. 1947. Spener and the Theology of Pietism. Journal of Bible and Religion 15: 46-49. [CrossRef]

Raghaviah, Jaiprakash. 1990. Basel Mission Industries in Malabar and South Canara 1834-1914: A Study of Its Social and Economic Impact. New Delhi: Gyan Publishing House.

Raghaviah, Jaiprakash. 2017. Conversion, Industrial Development and Social Engineering: Basel Mission in Malabar during the Nineteenth Century. Salesian Journal of Humanities and Social Sciences VIII: 1-10.

Raj, A. 1992. Discrimination against Dalit Christians in Tamil Nadu. Madurai: Ideas Centre.

Rambo, Lewis R. 1993. Understanding Religious Conversion. New Haven: Yale University Press.

Robinson, Rowena, and Sathianathan Clarke, eds. 2003. Religious Conversion in India: Modes, Motivations, and Meanings. New Delhi: Oxford University Press.

Robinson, Rowena. 1998. Conversion, Continuity, and Change: Lived Christianity in Southern Goa. New Delhi: Sage.

Sam, Jillet Sarah. 2014. Place and Caste Identification: Distanciation And Spatial Imaginaries on A Caste-Based Social Network. Ph.D. dissertation, University of Maryland, Baltimore, MD, USA. Available online: https://search.proquest.com/openview/ad613b030 08b782356d026d409348f93/1?pq-origsite=gscholar\&cbl=18750\&diss=y (accessed on 29 September 2020).

Sarkar, Kingshuk, and Rinju Rasaily. 2019. Family Labour in Small Holding Plantation Sector: A Study with Special Focus on Women and Children in Selected Areas of South India. Noida: V.V. Giri National Labour Institute.

Shah, Rebecca Samuel, and Joel Carpenter, eds. 2018. Christianity in India: Conversion, Community Development, and Religious Freedom. Minneapolis: Fortress Press.

Snow, David, and Richard Machalek. 1983. The Convert as a Social Type. Sociological Theory 1: 259-89. [CrossRef]

Srinivas, M. N. 1962. Caste in Modern India and Other Essays. New York: Asia Publishing House.

Stanley, Brian. 1990. The Bible and the Flag: Protestant Missions and British Imperialism in the Nineteenth and Twentieth Centuries. Leicester: Apollos.

Staples, C. L., and A. L. Mauss. 1987. Conversion or Commitment? A Reassessment of the Snow and Machalek Approach to the Study of Conversion. Journal for the Scientific Study of Religion 26: 133-47. [CrossRef]

Stenzl, Catherine. 2010. The Basel Mission industries in India 1834-1884 Improvisation or Policy? Master of Arts dissertation, University of London, London, UK. Available online: https://www.academia.edu/39797314/The_Basel_Mission_industries_in_ India_1834_1884_Improvisation_or_Policy (accessed on 4 June 2020). 
Stokes, W. 1883. Mission work on the Nilgiri Hills. In Report of the Second Decennial Missionary Conference Held at Calcutta 1882-1883. Edited by J. M. Mitchell and G. H. Rouse. Calcutta: J.W. Thomas Baptist Mission Press.

The Nilgiris District Statistical Handbook. 2001. Ooty: District Collector Office.

Thomssen, G. N. 1905. Samuel Hebich of India: The Master Fisher of Men. Cuttack: Orissa Mission Press.

Thonippara, Francis. 2000. St. Thomas Christians: The First Indigenous Church of India. In Christianity is Indian: The Emergence of an Indigenous Community. Edited by Roger E. Hedlund. Delhi: ISPCK.

Viswanath, Rupa. 2014. The Pariah Problem: Caste, Religion, and the Social in Modern India. New York: Columbia University Press.

Viswanathan, Gauri. 1998. Outside the Fold: Conversion, Modernity, and Belief. New Delhi: Oxford University Press.

Young, Richard Fox, ed. 2009. India and the Indianness of Christianity: Essays on Understanding- Historical, Theological, and Bibliographical in Honor of Robert Eric Frykenberg. Cambridge: W.B. Eerdmans Pub. 